\title{
Carbon Dioxide Sequestration Assessment through Pyrogenic Biomass: Case for Turkey
}

\author{
Zuhal Akyürek* \\ Faculty of Engineering and Architecture, Burdur Mehmet Akif Ersoy University, 15030 Burdur, Turkey
}

Received: 8 September 2020

Accepted: 31 October 2020

\begin{abstract}
Global climate change driven by anthropogenic activities have diverted the attention on the development of the methods for atmospheric carbon dioxide capturing and sequestration, the so called negative emission technologies (NETs). Pyrolysis is one of the most environmentally friendly conversion technologies for waste disposal that are being developed to convert waste materials into energy and valuable products. Biochar is high carbon content pyrogenic solid material obtained by thermal degradation of biomass in an oxygen-free medium. High nutrients content in biochar makes it a suitable material for soil amendment purposes. Furthermore, biochar acts as a carbon sink to reduce atmospheric greenhouse gas (GHG) emissions thus can play a significant role in the control of environmental pollutants by carbon negative emissions. In this study, the carbon dioxide sequestration potential assessment of a wide range of biomass including agricultural residues, forestry residues, livestock manure and municipal solid waste (MSW) in Turkey have carried out. The results revealed that pyrogenic carbon bio-sequestration in Turkey is possible with negative emissions potential of biomass is $60.38 \mathrm{Mton} \mathrm{CO} 2 \mathrm{eq} / \mathrm{year}$, which accounts for $16 \%$ of the total annual carbon dioxide emission. Biochar is an untapped resource for emission abatement strategies.
\end{abstract}

Keywords: biochar, carbon sequestration, biomass, pyrolysis, waste management

\section{Introduction}

Energy is a vital element of sustainable development. In the days of Corona pandemic, we clearly feel our need and dependency on electricity to carry out our lives at home. Together with continuously growing demand for electricity, rapid depletion in fossil fuel reserves, and increasing anthropogenic carbon dioxide emissions have risen the concerns on climate change and potential ecological

*e-mail: drzuhalakyurek@gmail.com damage, and thus have converted the attention on renewable energy sources.

Carbon dioxide levels in the atmosphere has been known to increase by $50 \%$ since the Industrial Revolution [1]. The mean global atmospheric $\mathrm{CO}_{2}$ concentration has raised to $407.4 \mathrm{ppm}$ in 2018. According to IPPC Report (2018), global warming is likely to reach $1.5^{\circ} \mathrm{C}$ between 2030 and 2052 if it continues to increase at the current rate [2]. Paris Agreement (2015) has aimed to keep the global temperature rise below 2 degrees Celsius above pre-industrial levels for this century. The Paris Agreement also required countries to present their "nationally determined contributions" (NDCs) to contribute to climate change mitigation efforts. In order 
to avoid severe consequences of climate change and to strengthen the global response, transition to cleaner power production is required via sustainable energy solutions [3].

Biomass in this regard, has gained more attention due to its promising potential for carbon sequestering as a low-carbon source for providing renewable energy. Biomass is the fourth largest energy source after oil, coal and natural gas, which provides about $14 \%$ of the world energy [4]. In the European Commission's Renewable Energy Development Report (2017), biomass is estimated to generate $20 \%$ of electricity in long term [5]. Biomass is a readily available and abundant source, which can be converted into solid, liquid and gaseous fuels. Biomass refers to organic materials derived from animals or plants, present in nature or generated from agricultural and industrial activities and urban wastes [6]. Energy potential from biomass strongly depends on the characteristics of the fuel, its availability and sustainable conversion technologies [7]. Negative emission technologies (NET) have taken attention in recent years in order to reduce carbon dioxide level in the atmosphere. Biomass combustion has recognized as the most appropriate way of bioenergy production with complementary carbon capture storage systems (CCS) according to the Fifth Assessment Report of International Panel on Climate Change [8]. Extraction of carbon dioxide from the atmosphere during photosynthesis makes biomass a renewable and environmentally friendly fossil fuel substitute. However, there may occur a risk of degradation of biomass carbon by microorganisms, which results in back release of GHG to the atmosphere. Pyrolytic carbon capture and storage on the other hand, can produce greater carbon sequestration efficiencies as a promising NET [9]. Biochar is considered as the one of only a few such technologies, and the one at highest technology readiness level.

Pyrolysis is thermal degradation of carbonaceous materials in inert atmosphere [10]. Pyrolysis yields bio-oil, syngas and solid product biochar. The quality, quantity and properties of the pyrolysis products depend mainly on the biomass characteristics (particle size, moisture content, volatile matter content, etc.) and on process conditions (heating rate, process temperature, residence time, inert gas flow rate, etc.) [11]. Pyrolysis process can be carried out via two routes as slow pyrolysis and fast pyrolysis. Slow pyrolysis differs from fast pyrolysis according to its lower the heating rate and longer residence time. In slow pyrolysis, biochar production favors $(50 \%)$, whereas in fast pyrolysis higher bio-oil yield is obtained [12]. Bio-oil can be upgraded to be used in transportation [13]. Pyrolysis products can either be utilized directly or used as fuel $[14,15]$. Bio-oil and syngas are generally combusted for producing green heat and power and release the carbon dioxide back to the atmosphere in carbon-neutral manner. However, biochar can lock high portion of the carbon content of raw biomass in stabilized form in long
Table 1. Production of agricultural products and number of animal stock in Turkey.

\begin{tabular}{|c|c|}
\hline \multicolumn{2}{|c|}{ Agricultural crops, tons [31] } \\
\hline Wheat & $19,000,000$ \\
\hline Sugar Cane & $18,085,528$ \\
\hline Corn & $6,000,000$ \\
\hline Olive & $1,525,000$ \\
\hline Tea & $1,450,000$ \\
\hline Almond & 150,000 \\
\hline Apricot & 846,606 \\
\hline Walnut & 225,000 \\
\hline Hazelnut & 776,046 \\
\hline Sunflower & $2,100,000$ \\
\hline Peanut & 169,328 \\
\hline Cotton & $2,200,000$ \\
\hline Banana & 548,323 \\
\hline Orange & $1,700,000$ \\
\hline \multicolumn{2}{|c|}{ Number of Animals [32] } \\
\hline Poultry & $359,217,862$ \\
\hline Sheep & $46,117,399$ \\
\hline Cattle & $17,497,113$ \\
\hline
\end{tabular}

term and hence contribute carbon-negative economy $[16,17]$. Biochar production has also considered as a potential waste management strategy for reducing the waste volume and elimination of pathogens especially for livestock manure [18]. In addition, heavy metal content of the biomass feedstock remains within biochar [10].

Biochar have a wide range of applications from wastewater treatment, heat and power production, to soil amendment. Soil application of biochar not only provides permanent capture of carbon dioxide $\left(\mathrm{CO}_{2}\right)$ emission, but also nitrous oxide $\left(\mathrm{N}_{2} \mathrm{O}\right)$ and methane $\left(\mathrm{CH}_{4}\right)$ emission, which have 28 and 300 times more potent greenhouse gas emission effect than $\mathrm{CO}_{2}$ in 100 years' time period, respectively [19]. Soil has inherent carbon content of 1550 GT organic and 950 GT inorganic carbon, corresponding to about $80 \%$ of the total carbon in terrestrial ecosystems [20]. Soil is also known to have additional $10-60 \mathrm{mg} \mathrm{C} /$ ha carbon sequestration potential [21]. The annual net removal of greenhouse gas (GHG) emission from the atmosphere through biochar to soil application has estimated approximately as 1-1.8 $\mathrm{Pg} \mathrm{CO}_{2}$ eq corresponding to $12 \%$ of the current anthropogenic $\mathrm{CO}_{2}$ emissions [22]. Compared to carbon capture and sequestration (CCS) biochar application is generally considered to be more economical [23]. Therefore, soil application of biochar 
has gained more interest in recent years due to its major benefits given below [21, 24, 25];

(i) Increasing the content and retention of organic matter in soil, which results in higher biodiversity, enhanced fertility and product yield to provide food security;

(ii) Replacing the synthetic fertilizer to provide agro-ecosystem security;

(iii) Attaining soil resilience against heavy rainfalls, erosion, etc., to provide clean water security;

(iv) Sequestering carbon and reducing the atmospheric concentrations of $\mathrm{CO}_{2}$ for overwhelming climate change threat to provide environmental security.

$\mathrm{CO}_{2}$ capturing and sequestration have been considered as one of the strategic routes to overcome the detrimental environmental impacts of anthropogenic emissions. Therefore, the development of efficient and low cost materials such as biochar has gained emphasis as a promising solution. Although NETs for controlling carbon dioxide emission have become a significant subject for sustainable development in Turkey, the number of studies on carbon capturing is very limited. To the author's knowledge, no previous studies estimate the carbon sequestration potential with biochar in Turkey. Hence, in the view of all the issues mentioned above, this study aims to estimate the possible quantity of carbon dioxide that could be sequestered with biochar using potential of biomass feedstock in Turkey including, agricultural residues, MSW and livestock manure and its contribution to long-term carbon dioxide reduction targets. The findings of this study emphasize the positive impact of sequestering carbon dioxide in soil through biochar production to fulfill the carbon dioxide emission reduction targets of Turkey.

\section{Materials and Methods}

\section{Energy Generation and Biomass Potential in Turkey}

Turkey is a developing country ranked among the World's 20 largest economies with her strategic geographical position and young population. Turkey is also ranked as the $7^{\text {th }}$ largest agricultural producer in the world [26]. Production and export of agricultural commodities and livestock farming activities have significant contribution to Turkish Economy. The food sector accounts for about $14.39 \%$ of the total GDP of manufacturing industry [27]. Agriculture is an indispensable sector for the Turkish economy. In this regard, the residues of agricultural and animal farming activities has potential to produce green energy and many other products [28]. Furthermore, the residues of

Table 2. Proximate analysis of biomass, wt $\%$.

\begin{tabular}{|c|c|c|c|c|c|}
\hline & Volatile Matter & Moisture & $\begin{array}{l}\text { Fixed } \\
\text { Carbon }\end{array}$ & Ash & HHV \\
\hline Wheat Straw [15] & 72.44 & 12.80 & 8.98 & 2.00 & 14.68 \\
\hline Sugarcane Bagasse [33] & 71.00 & 13.20 & 13.70 & 2.10 & 17.02 \\
\hline Corn Cob [15] & 79.51 & 12.80 & 5.70 & 2.00 & 16.00 \\
\hline Olive residue [34] & 74.40 & 10.40 & 13.80 & 1.40 & 18.73 \\
\hline Tea Waste [35] & 62.47 & 10.90 & 23.44 & 3.22 & 16.19 \\
\hline Almond Shell [36] & 80.30 & 10.00 & 9.10 & 0.60 & 18.33 \\
\hline Apricot Stone [37] & 78.00 & 6.70 & 14.00 & 1.20 & 19.09 \\
\hline Walnut Shell [38] & 74.00 & 5.43 & 15.57 & 5.00 & 16.68 \\
\hline Hazelnut Shell [34] & 62.40 & 8.70 & 27.60 & 1.00 & 20.20 \\
\hline Sunflower Residue [36] & 68.54 & 8.10 & 15.82 & 7.63 & 18.00 \\
\hline Peanut Shell [39] & 70.10 & 5.10 & 22.60 & 2.20 & 16.35 \\
\hline Cotton Residue [40] & 83.42 & 6.10 & 6.18 & 3.94 & 16.80 \\
\hline Banana Peel [41] & 66.79 & 8.53 & 20.55 & 4.13 & 18.87 \\
\hline Orange Peel [42] & 52.30 & 12.20 & 32.20 & 3.40 & 16.83 \\
\hline MSW [43] & 64.00 & 4.00 & 15.00 & 17.00 & 18.90 \\
\hline Poultry Manure [44] & 58.67 & 12.00 & 7.04 & 22.00 & 17.13 \\
\hline Cattle Manure [18] & 54.55 & 7.75 & 12.40 & 25.30 & 14.86 \\
\hline $\begin{array}{l}\text { Sheep Manure } \\
\text { (This study) }\end{array}$ & 72.00 & 9.00 & 17.00 & 2.00 & 9.16 \\
\hline
\end{tabular}


agricultural and livestock activities have contributed the GHG emissions if they are not used but stored on land. Electricity production in Turkey mainly relies on fossil resources. Electricity generation in Turkey in year 2018 was $304,802 \mathrm{GWh}$ and the share of the resources were $37.2 \%$ coal, $30.3 \%$ natural gas, $19.7 \%$ hydro, $12.7 \%$ renewables and waste and $0.1 \%$ liquid fuels [29].

Solid waste disposal is a worldwide environmental problem. Waste to energy conversion is a promising way to reduce the environmental risk of these wastes. In Turkey, total annual MSW production is 32.170.975 tons [30]. In this study, the biomass potential from agricultural residues, MSW, animal manure in Turkey utilized through biochar production and soil carbon sequestration have evaluated. The agricultural production data and animal stock that have collected from Turkish Statistical Institute (2019) [31] are presented in Table 1. Biomass feedstock in Turkey is composed of $38 \%$ agro-waste, $35 \%$ MSW and $27 \%$ animal waste by dry weight.

\section{Biomass Characteristics and Pyrolysis Operating Conditions}

Biomass type (volatile matter, fixed carbon, ash contents, etc.) and operating conditions of pyrolysis have significant influence on soil application of biochar to provide more benefits for the issues discussed above.
The proximate analysis of biomass used in this study is given in Table 2.

Slow pyrolysis process approximately yields $35 \%$ biochar, 30\% bio-oil, and 35\% syngas by weight [45]. Biochar production favours (over 50\% under) low operating temperatures of $400-550^{\circ} \mathrm{C}$ [46]. Low pyrolysis temperatures have also known to produce biochar with higher nutrients capacity compared to those created at higher temperatures $[47,48]$. The carbon content in biochar referred as stable carbon depends on the amount of non-volatile carbon in biomass. High carbon content in biochars makes behave like activated carbons [15]. Table 3 shown the pyrolysis conditions for the biomass types used in this study.

\section{Carbon Yield and Carbon Sequestration Potential}

The amount of carbon dioxide sequestration via biochar production was calculated as follows [49]:

Annual biochar production:

$$
B C=B \times \% b
$$

...where BC denotes the annual amount of biochar production (Mtons); B represents biomass production (Mtons) and $\mathrm{b}$ is the percentage of biochar yield.

Carbon content in biomass (Mtons) was calculated as:

Table 3. Operating conditions of biomass pyrolysis.

\begin{tabular}{|c|c|c|c|c|}
\hline Feedstock & Pyrolysis Temperature, ${ }^{\circ} \mathrm{C}$ & Heating Rate, ${ }^{\circ} \mathrm{C} / \mathrm{min}$ & Biochar Yield, \% & Reference \\
\hline Wheat Straw & 450 & 20 & 32.40 & {$[15]$} \\
\hline Sugar Cane Bagasse & 500 & 10 & 24.50 & {$[33]$} \\
\hline Corn Cob & 450 & 20 & 24.00 & {$[15]$} \\
\hline Olive Residue & 500 & 5 & 25.02 & {$[36]$} \\
\hline Tea Waste & 500 & 10 & 38.00 & {$[35,48]$} \\
\hline Almond Shell & 500 & 10 & 47.30 & {$[36]$} \\
\hline Apricot Stone & 500 & 25 & 36.10 & {$[37]$} \\
\hline Walnut Shell & 450 & 20 & 40.00 & {$[38]$} \\
\hline Hazelnut Shell & 500 & 10 & 41.10 & [34] \\
\hline Sunflower Residue & 550 & 5 & 36.00 & {$[36]$} \\
\hline Peanut Shell & 500 & 10 & 48.33 & [39] \\
\hline Cotton Residue & 500 & 10 & 28.00 & {$[40]$} \\
\hline Banana Peel & 350 & NA & 40.00 & {$[41]$} \\
\hline Orange Peel & 350 & NA & 32.50 & {$[42]$} \\
\hline MSW & 500 & 10 & 53.74 & {$[43]$} \\
\hline Poultry Manure & 500 & 15 & 55.80 & {$[44]$} \\
\hline Cattle Manure & 450 & 10 & 54 & {$[18]$} \\
\hline Sheep Manure & 450 & 10 & 52 & This study \\
\hline
\end{tabular}




$$
B_{\text {Carbon }}=B \times C_{\text {Biomass }} \%
$$

Carbon content in biochar (Mtons) was calculated as:

$$
B C_{\text {Carbon }}=B C \times C_{\text {Biochar }} \%
$$

...where $\mathrm{C}_{\text {Biomass }}$ and $\mathrm{C}_{\text {Biochar }}$ denote the percent carbon content of biomass and biochar, respectively.

From the carbon content and mass yield, the carbon yield representing the amount of carbon remaining in the biochar was calculated.

$$
\% \text { Carbon yield }=\frac{B C_{\text {Carbon }}}{B_{\text {Carbon }}} \times 100
$$

Carbon dioxide sequestration potential was determined by:

$$
C O_{2 E q}={ }_{B C_{C a r b o n}} \times \frac{M W_{C O 2}}{M W_{C}}
$$

...where $\mathrm{MW}_{\mathrm{C}}$ and $\mathrm{MW}_{\mathrm{CO} 2}$ are the molecular weight of carbon and carbon dioxide $12 \mathrm{~g} / \mathrm{mol}$ and $44 \mathrm{~g} / \mathrm{mol}$, respectively.

\section{Results and Discussion}

\section{Soil Application of Biochar}

Biochar derived from slow pyrolysis of biomass under oxygen-free environment is a carbon and nutrient rich material. Characteristics of biochar is vital for understanding its agricultural impacts. Biochar application to soil has known to have supportive effect on plant growth and crop yield due its high nutrient content, water retention ability, stability in soil, etc. for agronomic improvement and environmental management $[10,50]$. Biochar application differs from fertilizer application by its high water holding and slow nutrient releasing capability. Studies on incubation and greenhouse applications of biochar have shown that biochar addition improves chemical and physical properties of soil [51, 52]. Furthermore, the application of biochar together with fertilizer to soil have shown synergic effects on yield of crop production and have reduced the need for fertilizers [53].

Biochar properties generally differ from raw biomass. Some of the characteristics of biochar can be used for determination of its suitability for soil application. $\mathrm{C} / \mathrm{N}$ molar ratio of biochar has high impact on nitrogen release and stability of biochar in soil and the balance between $\mathrm{N}$ mineralization and $\mathrm{N}$ immobilization [54]. The $\mathrm{C} / \mathrm{N}$ molar ratios of biochar are illustrated in Fig. 1. $\mathrm{C} / \mathrm{N}$ molar ratio can be altered by using different types of biomass feedstock and/or changing the pyrolysis temperature. Higher pyrolysis temperature leads to higher $\mathrm{C} / \mathrm{N}$ ratio in biochar, however, the optimized pyrolysis temperature for biochar production is considered as $500{ }^{\circ} \mathrm{C}$ for efficient carbon recovery, cation exchange capacity, having stronger interactions with soil mineral particles [46]. Higher $\mathrm{C} / \mathrm{N}$ ratio $(>30)$ is also indicative of significant reduction of soil $\mathrm{N}_{2} \mathrm{O}$ emissions, which has 298 times more greenhouse effect than carbon dioxide within a time scale of 100 years $[54,55]$. The $\mathrm{C} / \mathrm{N}$ molar ratio $<20$ depicts net $\mathrm{N}$ mineralization whereas $\mathrm{C} / \mathrm{N}$ molar ratio $>30, \mathrm{~N}$ immobilization is expected [56]. As can be seen from Fig 1, the $\mathrm{C} / \mathrm{N}$ molar ratio of all the biochars except for tea waste, cotton residue, and animal manure are greater than 30 indicate decrease in net $\mathrm{N}$ mineralization in soil. On the other hand, soil $\mathrm{pH}$ increases with alkaline biochar addition, leading to increase in soil microbial activity, $\mathrm{N}$ mineralization and soil nitrification [57].

Biochar application to soil has also known to increase electrical conductivity and cation exchange

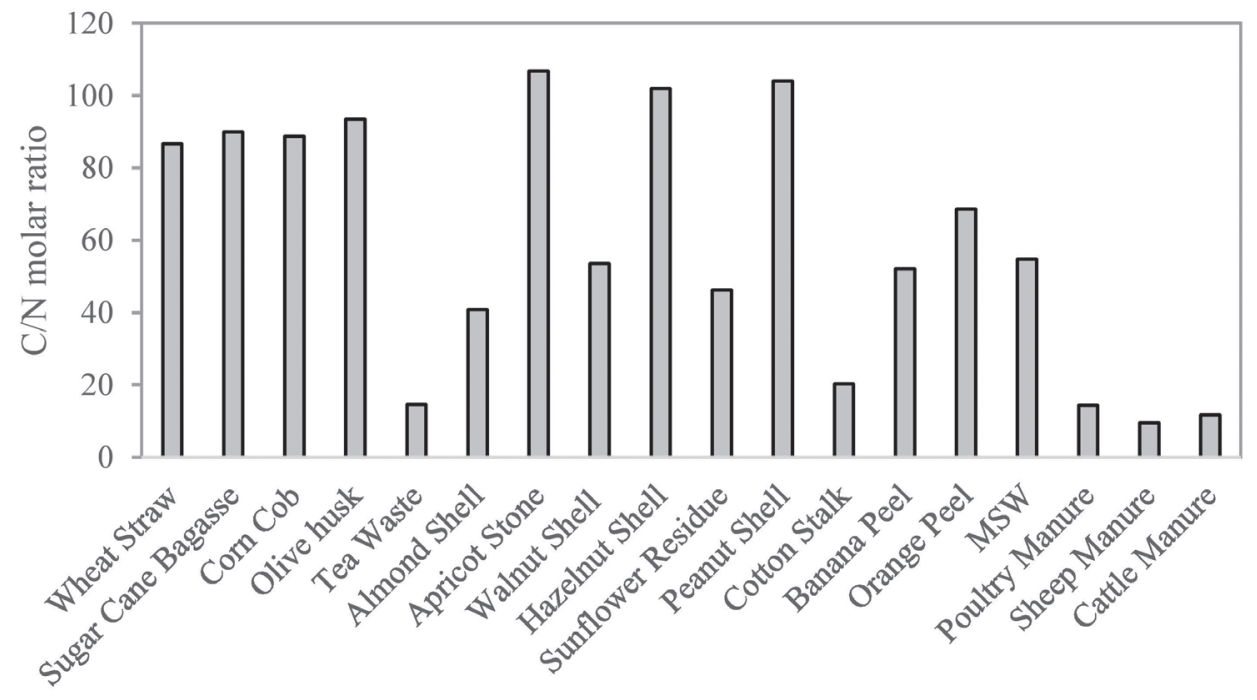

Fig. 1. $\mathrm{C} / \mathrm{N}$ molar ratio of biochar. 


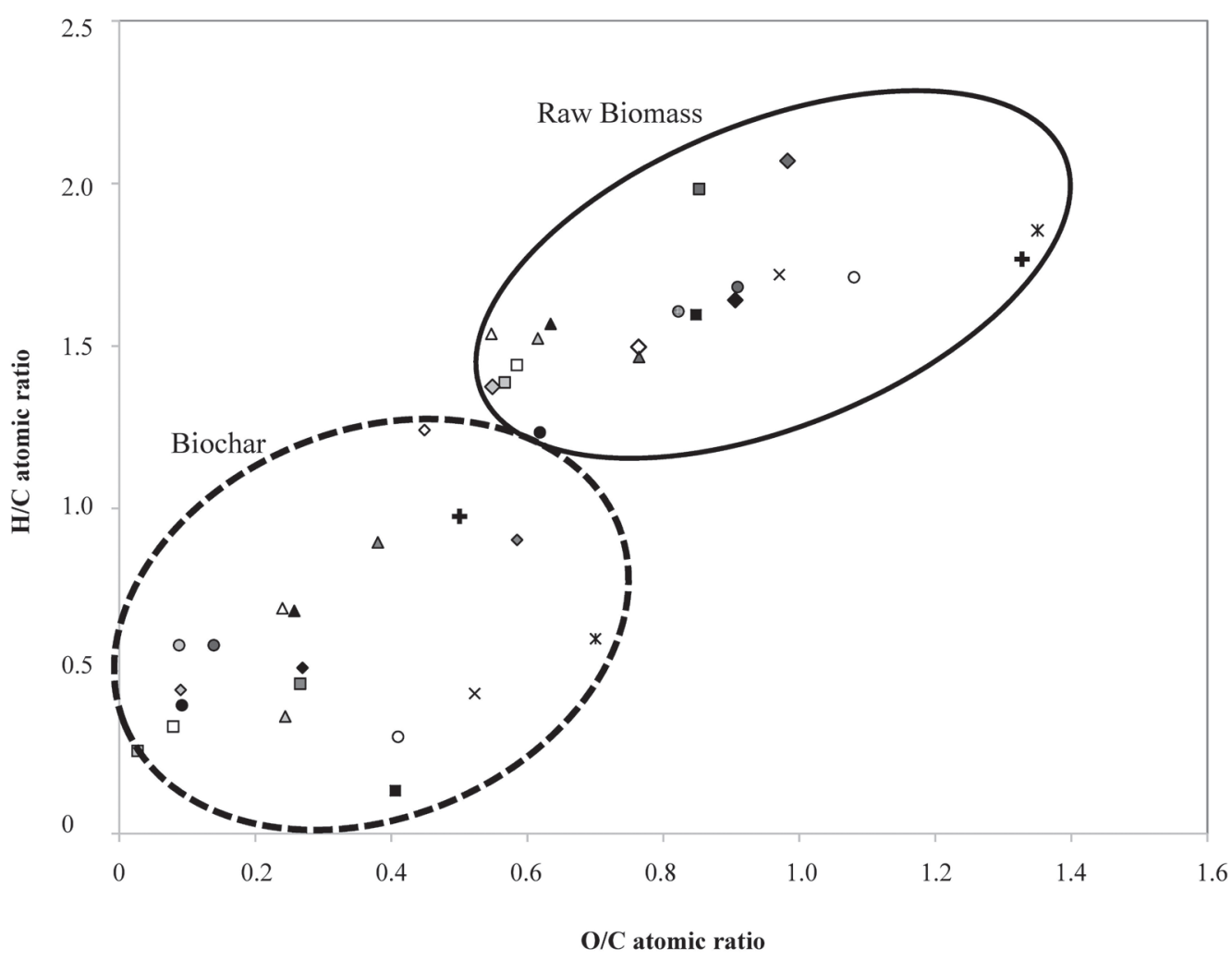

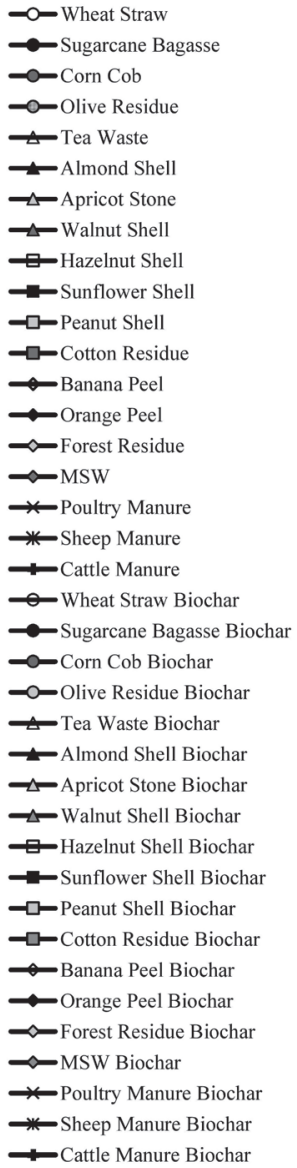

Fig. 2. Van Krevelen plot of biomass and biochar [Raw data: 15,18, 33-44].

capacity of soil. High surface area and negative surface charge in biochar provides more place for beneficial soil microorganisms and more binding sites for nutrient cations-anions and macro-nutrients $\mathrm{N}, \mathrm{P}, \mathrm{K}$ to retain in soil in a plant-available form [46, 51, 58]. An important advantage of biochar application to soil compared to synthetic fertilizers arose from its slowreleasing mechanism of nutrients in soils [50]. Biochar can act as an organic fertilizer with its high $\mathrm{C}, \mathrm{N}, \mathrm{P}$, $\mathrm{K}$ concentrations and water retention ability. Hydroxyl $(-\mathrm{OH})$ and carboxyl $(-\mathrm{COOH})$ known as polar functional groups on surface of biochar results in higher negative surface charge and higher cation exchange capacity to retain the nutrients in soil [10]. $\mathrm{H} / \mathrm{C}$ molar ratio indicates aromatization of organic matter and $\mathrm{O} / \mathrm{C}$ molar ratio reflects polar functional groups, hydrophobicity and stability of biochar in soil [58]. Van Krevelen Plot is useful method for predicting the chemical structure of biomass and biochar by interpretation of the chemical data. Van Krevelen diagram $(\mathrm{H} / \mathrm{C}$ molar ratio vs $\mathrm{O} / \mathrm{C}$ molar ratio) of biomass and biochar under consideration are presented in Fig. 2. Examination of the van Krevelen plot of various biomass and biochar revealed $\mathrm{H} / \mathrm{C}$ and $\mathrm{O} / \mathrm{C}$ molar ratios of biochar were found to be lower than those of raw biomass.

Lower molar ratios of $\mathrm{O} / \mathrm{C}$ are indicative of higher biomass stability. Half-life of biochar stability in soil can be predicted from the $\mathrm{O} / \mathrm{C}$ molar ratio. The $\mathrm{O} / \mathrm{C}$ molar ratio lower than 0.2 is predicted half-life of biochar is greater than 1000 years, when the ratio is between 0.2 and 0.6 the predicted half-life of biochar becomes 100 to 1000 years and when the molar ratio of $\mathrm{O} / \mathrm{C}$ in biochar is greater than 0.6 then, the half-life is predicted to be about 100 years [59]. $\mathrm{H} / \mathrm{C}$ ratio has also contributing impact on stability of biochar. $\mathrm{H} / \mathrm{C}$ lower than 0.4 shows high carbon sequestration potential [54]. As can be seen from Fig. 2, the half-life of biochar derived from sugarcane bagasse, corncob, olive residue, hazelnut shell and peanut shell have predicted to show longer stability in soil with half-life greater than 1000 years. Other biochar examined in this study except for sheep manure biochar, have predicted stability in soil with half-life of 100 to 1000 years. Lower pyrolysis temperature leads to production of more stable biochars [60].

Carbon conversion yield (Fig. 3) of biomass is another important factor for carbon sink and mitigation of carbon dioxide emissions. Based on the biomass production data total potential of carbon sequestration of biochar in Turkey has determined as 16.47 Mtons/year. Carbon dioxide sequestration potential of biochar-soil application in Turkey has determined as 60.38 Mtons/year, which accounts for about $16 \%$ of the total carbon dioxide emissions in 


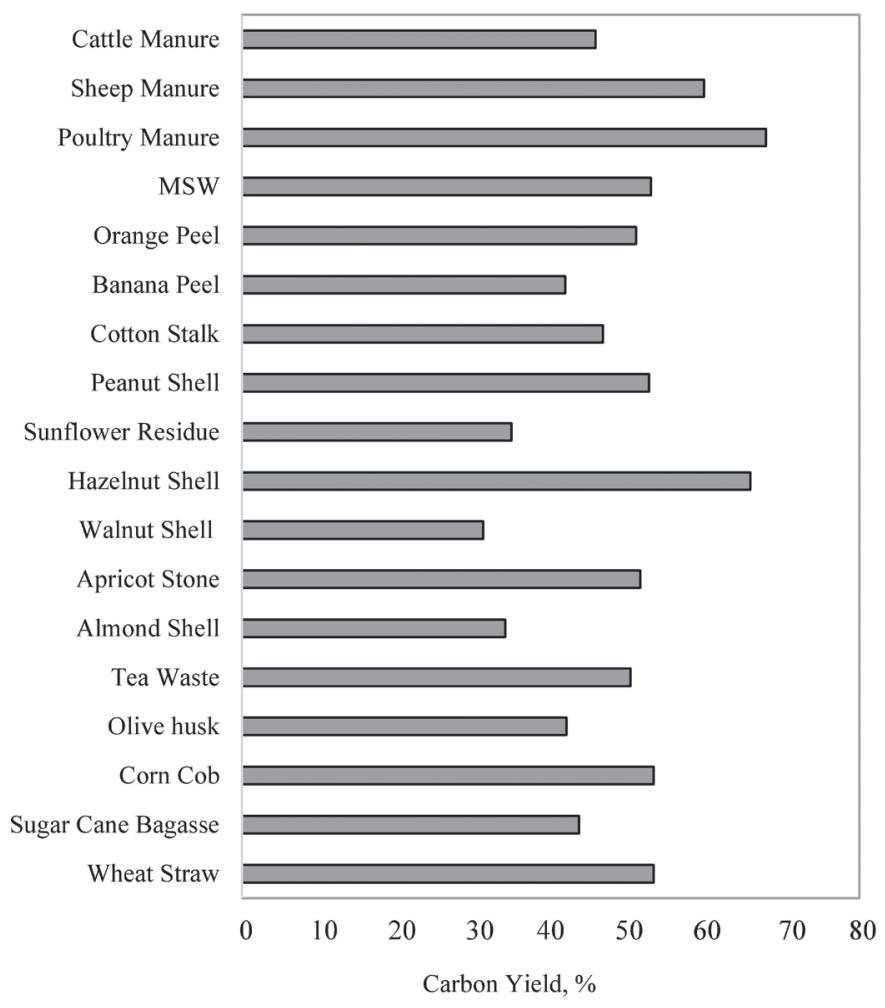

Fig. 3. Carbon conversion of biomass [Raw data: 15,18, 33-44].

Turkey. Biochar derived from agro-waste, MSW and animal manure have shown annual carbon dioxide sequestration potential of 22.98 Mtons (38\%), 25.00 Mtons (41\%) and 12.49 Mtons (21\%), respectively.

Soil has significant capacity to sequester carbon dioxide through the implementation of improved waste and land management practices. Spreading biochar application in agricultural soils would be an achievable practice for reducing the atmospheric carbon dioxide emissions on one hand, for producing efficient agricultural crops on the other.

\section{Conclusions}

The climate change issue at the global level has raised the attention on ecological solutions for carbon dioxide sequestering. To reduce the atmospheric greenhouse gas emissions biochar utilization has become one of the most promising options. In view of the above discussion on biochar application to soil, the following parameters can be pointed out for obtaining high potential of carbon dioxide sequestration from biomass:

- The biochar chemical composition and pyrolysis conditions have significant impact on biochar yield, stability of biochar in soil and carbon sequestration potential.

- $\mathrm{C} / \mathrm{N}$ molar ratio of biochar greater than 30 (biochar from wheat straw, sugarcane bagasse, corn cob, olive residue, almond shell, apricot stone, walnut shell, hazelnut shell, sunflower, peanut shell, banana peel, orange peel, MSW), is also indicative of $\mathrm{N}$ immobilization in soil and significant reduction of soil $\mathrm{N}_{2} \mathrm{O}$ emissions.

- O/C molar ratio < 0.2 (sugarcane bagasse, peanut shell) and high carbon yield indicate above 1000 years stability of biochar in soil.

From the data analysed, carbon dioxide sequestration potential of biochar-soil application in Turkey has been determined as 60.38 Mtons/year, accounts for $16 \%$ of the annual carbon dioxide emissions in Turkey. The results reveal that biochar can be a beneficial agronomic strategy for increasing crop yield and soil productivity in Turkey. Biochar application to soil offers a longterm sink for atmospheric carbon dioxide emission to mitigate climate change.

\section{Acknowledgements}

Financial support provided by Burdur Mehmet Akif Ersoy University through a research project BAP-0576-YL-19 in aid of this research is gratefully acknowledged.

\section{Conflict of Interest}

The author declares no conflict of interest. 


\section{References}

1. PIRES J.C.M. Negative emissions technologies: A complementary solution for climate change mitigation. Science of the Total Environment, 167, 502, 2019.

2. IPPC Special Report "Global Warming of $1.5^{\circ} \mathrm{C}$ ". https:// report.ipcc.ch/sr15/pdf/sr15_spm_final.pdf (Accessed on 07.09.2020)

3. Paris Agreement, Nationally Determined Contributions (NDCs). https://unfecc.int/nationally-determinedcontributions-ndes (Accessed on 07.09.2020)

4. World Energy Resources Report, World Energy Council. https://www.worldenergy.org/assets/images/ imported/2016/10/World-Energy-Resources-Fullreport-2016.10.03.pdf (Accessed on 07.09.2020)

5. European Commission's Renewable Energy Development Report https://ec.europa.eu/commission/sites/betapolitical/files/report-renewable-energy en.pdf (Accessed on 07.09.2020)

6. AKYUREK Z. Energy Potential from Animal Manure: Biogas Potential of Burdur, Eskisehir Technical University Journal of Science and Technology A- Applied Sciences and Engineering, 20 (2), 161, 2019.

7. TERRAPON-PFAFF J.C., FISCHEDICK M., MONHEIM $H$. Energy potentials and sustainability - the case of sisal residues in Tanzania, Energy for Sustainable Development, 16, 312, 2012.

8. ALLEN M.R., BARROS V.R., BROOME J., CRAMER W., CHRIST R., CHURCH J.A., EDENHOFER O. IPCC fifth assessment synthesis report - Climate Change 2014 synthesis report. https://www.ipcc.ch/report/ar5/syr/ (Accessed on 07.09.2020)

9. SCHMIDT H.P., ANCA-COUCE A., HAGEMANN N., WERNER C., GERTEN D., LUCHT W., KAMMANN C. Pyrogenic carbon capture and storage. Global Change Biology Bioenergy, 11, 573, 2019.

10. LEHMANN J. Biochar for environmental management: an introduction Biochar for Environmental Management. Sci. Technol. 25, 15801, 2009.

11. WEBER K., QUICKER P. Properties of biochar. Fuel, 217, 240, 2018.

12. QIAN K., KUMAR A., ZHANG H., BELLMER D., HUHNKE R. Recent advances in utilization of biochar. Renewable and Sustainable Energy Reviews, 42, 1055, 2015.

13. LEIBOLD H., HORNUNGA A., SEIFERTA H. HTHP syngas cleaning concept $f$ two stage biomass gasifi cation for FT synthesis. Powder Technology 180, 265, 2008.

14. YIN R., LIU R., MEI J.Y., FEI W., SUN X. Characterization of bio-oil and biochar obtained from sweet sorghum bagasse fast pyrolysis with fractional condensers, Fuel 112, 96, 2013.

15. BISWAS B., PANDEY N., BISHT Y., SINGH R., KUMAR J., BHASKAR T. Pyrolysis of agricultural biomass residues: Comparative study of corncob, wheat straw, rice straw and rice husk. Bioresource Technology, 237, 57, 2017

16. VANHOLME B., DESMET T., RONSSE F., RABAEY K., VAN BREUSEGEM F., DE MEY M. Towards a carbon negative sustainable bio-based economy. Front. Plant Sci. 4, 174, 2013.

17. SHARMA S.P. Biochar for Carbon Sequestration: Bioengineering for Sustainable Environment. Omics Technologies and Bio-Engineering, Elsevier Inc, .Ed. Vasco Azevedo, Debmalya Barh, 2018.
18. AKYÜREK Z. Sustainable Valorization of Animal Manure and Recycled Polyester: Co-pyrolysis Synergy, Sustainability, 11 (8), 2280, 2019.

19. DOWNIE A., CROSKY A., MUNROE P. Biochar for environmental management. Earthscan Publications Ltd, Sterling, Physical properties of biochar. In: Lehmann J, Joseph S (eds), 2009.

20. MAJUMDER S., NEOGI S., DUTTA T., POWEL M.A., BANIK P. The impact of biochar on soil carbon sequestration: Meta-analytical approach to evaluating environmental and economic advantages. Journal of Environmental Management, 250, 109466, 2019.

21. STOUT B., LAL R., MONGER C., Carbon capture and sequestration: the roles of agriculture and soils. Int. J. Agric. Biol. Eng. 9 (1), 1, 2016.

22. PAUSTIAN K., LEHMANN J., OGLE S., REAY D., ROBERTSON G.P., SMITH P. Climate smart soils. Nature 532 (7597), 49, 2016.

23. JUNG S., PARK Y.K., KWON E.E. Strategic use of biochar for $\mathrm{CO}_{2}$ capture and sequestration, Journal of $\mathrm{CO}_{2}$ Utilization 32, 128, 2019.

24. OLSON K., AL-KAISI M., LAL R., LOWERY R. Experimental consideration, treatments, and methods in determining soil organic carbon sequestration rates. Soil Science Society of America Journal, 78 (2) 348, 2014.

25. LAL R. Managing terrestrial carbon in a changing climate. Chp 1 in Soil Security for Ecosystem Management: Mediterranean Soil Ecosystems 1. Springer. ISBN: 978-3319-00699-4, 2014

26. Food and Agricultural Organization of the United Nations (FAO), http://www.fao.org/turkey/fao-in-turkey/turkey-ata-glance/en/ (Accessed on 08.09.2020)

27. AKYUREK Z. LMDI decomposition analysis of energy consumption of Turkish manufacturing industry: 2005-2014, Energy Efficiency, 13, 649, 2020.

28. AKYUREK Z. Energy Recovery and Greenhouse Gas Emission Reduction Potential of Bio-Waste in the Mediterranean Region of Turkey, El-Cezerî Journal of Science and Engineering, 6 (3) 482, 2019.

29. Turkish Electricity Transmission Corporation (TEİAŞ) Electricity generation in Turkey (2019). https://www.teias. gov.tr/ (Accessed on 08.09.2020)

30. International Energy Agency, https://www.iea.org/ countries/turkey (Accessed on 08.09.2020)

31. Turkish Statistical Institute, 2019 http://www.tuik.gov.tr/ (Accessed on 08.09.2020)

32. Biomass Map of Turkey. https://bepa.enerji.gov.tr/ (Accessed on 08.09.2020)

33. LEE Y., PARK J., RYU C., GANG K.S., YANG W., PARK Y.K., JUNG J., HYUN S. Comparison of biochar properties from biomass residues produced by slow pyrolysis at 500 C. Bioresource Technology 148, 196, 2013.

34. DEMIRBAS A. Effect of temperature on pyrolysis products from four nut shells. J. Anal. Appl. Pyrolysis 76, $285,2006$.

35. DEMIRBAS A. Effects of temperature and particle size on bio-char yield from pyrolysis of agricultural residues. J. Anal. Appl. Pyrolysis 72, 243, 2004.

36. GONZALEZ J.F., ROMAN S., ENCINAR J.M., MARTINEZ G. Pyrolysis of various biomass residues and char utilization for the production of activated carbons. J. Anal. Appl. Pyrolysis 85, 134, 2009.

37. GERÇEL H.F., ÇAYIR G., GERÇEL O. Energy Applications of Biomass: Pyrolysis of Apricot Stone. Energy Sources, Part A, 28 (7), 611, 2006. 
38. YILDIZ Z., CEYLAN S. Pyrolysis of walnut shell biomass in fluidized bed reactor: Determination of optimum conditions for bio-char production. Environmental Research \& Technology, 1 (4), 47, 2018.

39. GALINATO S.P., YODER J.K., GRANATSTEIN D. The economic value of biochar in crop production and carbon sequestration. Energy Policy 39, 6344, 2011.

40. WINDEATT J.H., ROSS A.B., WILLIAMS P.T., FORSTER P.M., NAHIL M.A., SINGH S. Characteristics of biochars from crop residues: Potential for carbon sequestration and soil amendment. Journal of Environmental Management 146, 189, 2014.

41. TAHIR I., ALI Z., ABBAS A., HUSSAIN Z., RAFIQUE S.F., DONG C.Q., LU Q. Fast Pyrolysis of Agricultural Residue: A Sustainable Way to Produce Clean Energy Fresenius Environmental Bulletin 28, 1253, 2019.

42. LAM S.S., LIEW R.K., CHENG C.K., RASIT N., OOI C.K., MA N.L., NG J.H., LAM W.H., CHONG C.T., CHASE H. Pyrolysis production of fruit peel biochar for potential use in treatment of palm oil mill effluent. J Env. Manag. 213 400, 2018.

43. BUAH W.K., CUNLIFFE A.M., WILLIAMS P.T. Characterization of Products from the Pyrolysis of Municipal Solid Waste. Process Safety and Environmental Protection, 85 (5), 450, 2007.

44. BAVARIANI M.Z., RONAGHI A., GHASEMI R.. Influence of pyrolysis temperatures on FTIR analysis, nutrient bioavailability, and agricultural use of poultry manure biochars, Communications in Soil Science and Plant Analysis, 2019.

45. GOYAL H.B., SEAL D., SAXENA R.C. Bio-fuels from thermochemical conversion of renewable resources: A review. Renew Sustain Energy Rev 12, 504, 2008.

46. LEHMANN J. Bio-energy in the black. Front Ecol Environ 5 (7) 381, 2007.

47. DAY D., EVANS R.J., LEE J.W., REICOSKY D. Economical $\mathrm{CO}_{2}$, $\mathrm{SOx}$, and $\mathrm{NOx}$ capture from fossil-fuel utilization with combined renewable hydrogen production and large-scale carbon sequestration, Energy, 30, 2558, 2005.

48. UZUN B.B., VAROL-APAYDIN E., ATEŞ F., ÖZBAY N., PÜTÜN A. Synthetic fuel production from tea waste: Characterisation of bio-oil and bio-char, Fuel 89, 176, 2010.

49. STOYLE A., Biochar production for carbon sequestration, 2011. https://web.wpi.edu/Pubs/E-project/Available/Eproject-031111-153641/unrestricted/BIOCHAR_CO2SEQ. pdf (Accessed on 08.09.2020)
50. HOSSAIN M.K., STREZOV V., CHAN K.Y., ZIOLKOWSKI A., NELSON P.F. Influence of pyrolysis temperature on production and nutrient properties of wastewater sludge biochar. J. Environ. Manag. 92, 223, 2011.

51. ATKINSON C., FITZGERALD J., HIPPS N. Potential mechanisms for achieving agricultural benefits from biochar application to temperate soils: a review. Plant Soil. 337, 1,2010

52. BUSSCHE W.J., NOVAK J.M., EVANS D.E., WATTS D.W., NIANDOU M.A.S., AHMEDN A. Influence of pecan biochar on physical properties of a Norfolk loamy sand. Soil Sci. 175, 10, 2010.

53. MACÍAS F., ARBESTAIN M.C. Soil carbon sequestration in a changing global environment. Mitig Adapt Strateg Glob Change 15, 511, 2010.

54. BRASSARD P., GODBOUT S., RAGHAVAN V. Soil biochar amendment as a climate change mitigation tool: Key parameters and mechanisms involved, Journal of Environmental Management 181, 484, 2016.

55. SOLOMON S., DAHE Q., MANNING M., et al. (eds), IPCC, Climate Change, Cambridge Univ. Press, New York, 2007.

56. HAGEMANN N., HARTER J., BEHRENS S. Elucidating the impacts of biochar applications on nitrogen cycling microbial communities, in Biochar Application: Essential Soil Microbial Ecology. Elsevier, ed. TK Ralebitso, CH Orr. ISBN: 978-0-12-803433-0, 2016.

57. MAJOR J., STEINER C., DOWNIE A., LEHMANN J. Biochar effects on nutrient leaching. Chapter 15. In: Lehmann J, Joseph S (eds) Biochar for environmental management science and technology. Earthscan, London, 271, 2009.

58. SPOKAS K.A, KOSKINEN W.C., BAKER J.M., REICOSKY D.C. Impacts of wood-chip biochar additions on greenhouse gas production and sorption/degradation of two herbicides in a Minnesota soil. Chemosphere 77, 574, 2009.

59. SPOKAS K.A. Review of the stability of biochar in soils: predictability of O:C molar ratios. Carbon Management, 1 (2), 289, 2010.

60. MUKOME F.N.D., ZHANG X., SILVA L.C.R., SIX J., PARIKH S.J. Use of chemical and physical characteristics to investigate trends in biochar feedstocks. J Agri. Food Chem. 61, 2196, 2013. 